九州大学学術情報リポジトリ

Kyushu University Institutional Repository

\title{
Improvement of Nutritive Value of Rice Straw by Treatment with Ammonia and Sulphur Dioxide
}

Song, Young-Han

Department of Animal Science, Faculty of Agriculture, Kyushu University

Shimojo, Masataka

Department of Animal Science, Faculty of Agriculture, Kyushu University

Goto, Ichiro

Department of Animal Science, Faculty of Agriculture, Kyushu University

https://doi.org/10.5109/23979

出版情報 : 九州大学大学院農学研究院紀要. 36 (1/2)，pp.143-149，1991-10. Kyushu University バージョン：

権利関係 : 


\title{
Improvement of Nutritive Value of Rice Straw by Treatment with Ammonia and Sulphur Dioxide
}

\author{
Young-Han Song, Masataka Shimojo and Ichiro Goto \\ Department of Animal Science, Faculty of Agriculture, \\ Kyushu University, Fukuoka 812, JAPAN
}

(Received July 30, 1991)

\begin{abstract}
An experiment was carried out to investigate the effects on the nutritive value of rice straw treated with anhydrous ammonia $(30 \mathrm{~g} / \mathrm{kg} \mathrm{DM})$ for 28 days at $20^{\circ} \mathrm{C}$ and/or sulphur dioxide $(40 \mathrm{~g} / \mathrm{kg} \mathrm{DM})$ for 24 hours at $20^{\circ} \mathrm{C}$. Rice straw was moistened with water (300 or 450 $\mathrm{g} / \mathrm{kg}$ ) prior to the treatment. In sacco digestibility of the sample was measured by suspending 5 nylon bags each for 48 hours in the rumen of Tokara goats fitted with a rumen cannular and fed on alfalfa hay. Ammonia and $\mathrm{NH}_{3} \cdot \mathrm{SO}_{2}$ treatments improved the crude protein content of rice straw approximately by 4 -fold to 4.5 -fold and the latter treatment gave slightly higher value than the former. Contents of NDF and hemicellulose were reduced by ammoniation and $\mathrm{NH}_{3} \cdot \mathrm{SO}_{2}$ treatment, however ADF and cellulose contents were little affected. Lignin and silica contents were reduced by ammonia and $\mathrm{NH}_{3} \cdot \mathrm{SO}_{2}$ treatments. These two treatments improved the digestibility in sacco of rice straw and its cell wall components, and straw digestibility was slightly improved with $\mathrm{NH}_{3} \cdot \mathrm{SO}_{2}$ than with $\mathrm{NH}$,. Improvement in digestibility was correlated with decrease in contents of lignin and silica and increased digestibility of lignin. Sulphuration alone less affected the nutritive value of rice straw compared to the other treatments.
\end{abstract}

\section{INTRODUCTION}

In Asia abundant quantities of rice straws are produced as a by-product of rice. Rice straw has a potential as feed for ruminants, however the production of animals fed on it is actually low.

Ammonia treatment of straws improves their digestibilities by up to $\mathbf{2 0 \%}$ and increases non-protein nitrogen contents (Waagepetersen and Vestergaard Thomsen, 1977). Ammoniation process is enhanced through the addition of water to straws (Waiss et al., 1972). Ben-Ghedalia and Miron (1981, 1984) reported that sulphur dioxide treatment also increases the digestibility in vitro of moist wheat straw by $40 \%$. Recently, combination uses of some chemicals have been investigated to give greater improvements in the nutritive values of cereal straws (Borhami and Sundst $\phi 1,1982$; Borhami et al., 1982 ; Horton et al., 1982 ; Streeter and Horn, 1982 ; Fahmy and $\boldsymbol{\Phi}$ rskov, 1984 ; Ben-Ghedalia and Miron, 1984). Ammoniation followed by sulphuration, compared to ammoniation alone, retained a higher amount of $\mathrm{NH},-\mathrm{N}$ in the straw and further increased straw digestibility by hydrolyzing cellulose and reducing cell wall organic matter (Dryden and Leng, 1986, 1988). It is also important to investigate the effects of these treatments on lignin and silica, the removal of which increases straw digestibility. More detailed studies are needed to elucidate the process of improvement in digestion of rice straws treated with $\mathrm{NH}$, and $\mathrm{SO}$,

The objective of this study is to investigate the effects of anhydrous ammonia, 
sulphur dioxide and combinations of them on nutritive value of rice straw.

\section{MATERIALS AND METHODS}

\section{Straw samples}

Straw from rice plants (japonica type, var. Nihonbare) was collected at the Kyushu University Farm in 1989. The straw was dried for $48 \mathrm{hr}$ at $70^{\circ} \mathrm{C}$ and cut in 1$2 \mathrm{~cm}$ length.

\section{Treatments}

Rice straw was moistened with water (300 or $450 \mathrm{~g} / \mathrm{kg} \mathrm{DM})$ and incubated at $20^{\circ} \mathrm{C}$ for 4 days in a sealed polyvinyl bag. The prepared straw was then treated with anhydrous ammonia ( 0 or $30 \mathrm{~g} / \mathrm{kg} \mathrm{DM}$ ) for 28 days at $20^{\circ} \mathrm{C}$ and followed by sulphur dioxide treatment $(0$ or $40 \mathrm{~g} / \mathrm{kg} \mathrm{DM})$ for $24 \mathrm{hr}$ at $20^{\circ} \mathrm{C}$.

\section{Analytical methods}

The treated straws were aired for 3 days to exclude excess chemicals and ground through a $1 \mathrm{~mm}$ aperture screen. Crude protein content was determined by the Kjeldahl method (AOAC, 1984) and ash content by combustion at $600^{\circ} \mathrm{C}$ for $3 \mathrm{hr}$. Cell wall components were determined by the methods of Georing and van Soest (1970). Lignin was determined by Morrison's method (1972). The straw digestibility in the rumen for $48 \mathrm{hr}$ was determined by suspending 5 nylon bags each for $48 \mathrm{hr}$ in the rumen

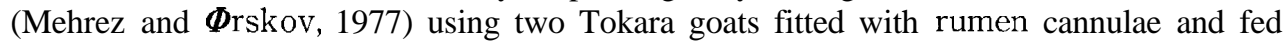
on alfalfa hay.

\section{Statistical analysis}

The digestibility and chemical components were fitted to analysis of variance difference and the least significant difference (LSD). The relations between digestibility and content of lignin or silica were discussed using linear regression analysis.

\section{RESULTS AND DISCUSSION}

\section{Effects of ammonia and sulphur dioxide treatments on chemical composi- tion of rice straw}

The chemical composition of untreated rice straw and moist rice straw treated with $\mathrm{NH}$, and $\mathrm{SO}$, is shown in Table 1. Ammoniation improved the crude protein content approximately by 4-fold. Sulphuration did not affect the crude protein content, however SO, application after ammoniation increased it by 4.5 times slightly higher than in the ammonia treatment. Crude protein content was slightly more improved with a $45 \%$ moisture level than with a $30 \%$ level, because a higher moisture content retained a higher amount of nitrogen in the straw.

Neutral detergent fibre (NDF) and hemicellulose contents were reduced greatly by ammoniation and $\mathrm{NH}_{3} \cdot \mathrm{SO}_{2}$ treatment. Acid detergent fibre (ADF) and cellulose were slightly reduced by ammonia and $\mathrm{NH}_{3} \cdot \mathrm{SO}_{2}$ treatments.

Contents of lignin and silica were reduced by ammonia and $\mathrm{NH}, \bullet \quad \mathrm{SO} 2$ treatments. These two treatments decreased silica more than they decreased lignin. Silica is more 
easily removed by alkali than is lignin (Jackson, 1977). Sulphuration seemed to have little effect on cell wall components due to its mild condition $\left(40 \mathrm{~g} / \mathrm{kg}\right.$ for $24 \mathrm{hr}$ at $\left.20^{\circ} \mathrm{C}\right)$, although there was a slight decrease in silica content.

\section{Effects of ammonia and sulphur dioxide treatments on in sacco digestibility of rice straw}

Table 2 shows the digestibilities of dry matter (DM), organic matter (OM) and cell wall components of rice straw treated chemically. Ammoniation increased the digestibilities of $\mathrm{DM}$ and $\mathrm{OM}$ by approximately $30 \%$, respectively. Application of SO, after ammonia treatment gave slightly higher straw digestibilities compared to ammoniation.

Treatment with $\mathrm{NH}$, or $\mathrm{NH}_{3} \cdot \mathrm{SO}_{2}$ greatly increased the digestibilities of $\mathrm{NDF}$, ADF, hemicellulose and cellulose. Sulphuration after ammoniation, compared to ammonia alone, produced higher digestibilities of all four fibres with a $30 \%$ moisture

Table 1. Effect of $\mathrm{NH}$, and $\mathrm{SO}_{2}$ treatments on chemical composition') of rice straw with different moisture contents.

\begin{tabular}{|c|c|c|c|c|c|c|c|c|c|c|}
\hline \multirow{3}{*}{$\begin{array}{l}\text { Moisture } \\
\mathrm{NH}, \\
\mathrm{SO}_{2}\end{array}$} & \multirow{3}{*}{$\begin{array}{l}(\%) \\
(\%) \\
(\%)\end{array}$} & \multirow{3}{*}{$\begin{array}{l}0 \\
0 \\
0\end{array}$} & \multicolumn{4}{|c|}{30} & \multicolumn{4}{|c|}{45} \\
\hline & & & \multicolumn{2}{|c|}{0} & \multicolumn{2}{|c|}{3} & \multicolumn{2}{|c|}{0} & \multicolumn{2}{|c|}{3} \\
\hline & & & 0 & 4 & 0 & 4 & 0 & 4 & 0 & 5 \\
\hline \multicolumn{2}{|c|}{ Crude protein } & 4. $6^{\mathrm{b} 5)}$ & $4.4^{\mathrm{ab}}$ & $4.2 "$ & $17.7^{\prime \prime}$ & $19.7^{\mathrm{d}}$ & $4.7^{\mathrm{b}}$ & $4.5^{\mathrm{ab}}$ & $20.4 ”$ & 21.0 \\
\hline \multicolumn{2}{|c|}{$\mathrm{NDF}^{2 !}$} & $67.2^{\mathrm{b}}$ & $67.9 ”$ & $65.9^{\prime}$ & $56.0 "$ & $56.9^{d}$ & $66.8^{\mathrm{b}}$ & 65.6 & $55.7 ”$ & 52.1 \\
\hline \multicolumn{2}{|l|}{$\mathrm{ADF}^{3)}$} & 39.2 & $41.3 ”$ & $38.9^{\prime}$ & $36.8^{\prime \prime}$ & $37.8^{\mathrm{d}}$ & $40.8^{b}$ & 38.8 & $36.8^{\prime \prime}$ & 34.1 \\
\hline \multicolumn{2}{|c|}{ Hemicellulose } & $28.1 "$ & $26.6^{\mathrm{ab}}$ & $27.0^{\mathrm{ab}}$ & 19.2 & $19.2^{\prime}$ & $26.0^{\mathrm{b}}$ & $26.8^{\mathrm{ab}}$ & $18.9 "$ & $18.0^{\prime}$ \\
\hline \multicolumn{2}{|c|}{ Cellulose } & $34.8^{\prime}$ & $37.1 "$ & $34.9^{\mathrm{b}}$ & 33.2 & $34.8^{b}$ & $37.0^{\mathrm{a}}$ & $35.0^{\mathrm{b}}$ & $33.6 "$ & $31.8^{\mathrm{d}}$ \\
\hline \multicolumn{2}{|l|}{$\mathrm{ABL}^{4)}$} & $9.3 "$ & 9.7 & $9.4 "$ & 7.4 & $8.2^{\mathrm{b}}$ & $9.7 ”$ & $9.5^{\mathrm{a}}$ & $7.7^{\prime}$ & $8.4^{\mathrm{b}}$ \\
\hline \multicolumn{2}{|l|}{ Silica } & $8.7^{\prime \prime}$ & $8.0^{\mathrm{b}}$ & 7.4 & $6.1^{\mathrm{e}}$ & $6.4^{\text {de }}$ & $7.6^{\mathrm{bc}}$ & $6.7^{\mathrm{d}}$ & $4.9^{\circ}$ & $3.3^{8}$ \\
\hline
\end{tabular}

1) \% Dry matter basis, ${ }^{2)}$ Neutral detergent fibre, ${ }^{3)}$ Acid detergent fiber,

4) Acetyl bromide lignin,

5) Figures with different superscripts in the same row differ significantly $(\mathrm{P}<0.01)$.

Table 2. Effect of $\mathrm{NH}$, and $\mathrm{SO}$, treatments on digestibilites in sacco of rice straw with different moisture contents.

\begin{tabular}{|c|c|c|c|c|c|c|c|c|c|}
\hline \multirow{3}{*}{$\begin{array}{l}\text { Moisture } \\
\mathrm{NH}_{3} \\
\mathrm{SO}_{2}\end{array}$} & \multirow{3}{*}{$\begin{array}{l}0 \\
0 \\
0\end{array}$} & \multicolumn{4}{|c|}{30} & \multicolumn{4}{|c|}{45} \\
\hline & & \multicolumn{2}{|c|}{0} & \multicolumn{2}{|c|}{3} & \multicolumn{2}{|c|}{0} & \multicolumn{2}{|c|}{3} \\
\hline & & 0 & 4 & 0 & 4 & 0 & 4 & 0 & 4 \\
\hline $\mathrm{DM}^{1 \prime}$ & $47.5^{\mathrm{ab} 6)}$ & $46.5^{\prime \prime}$ & $50.1^{\mathrm{ab}}$ & $78.1 ”$ & $80.9 "$ & $48.1^{\mathrm{ab}}$ & $51.2^{\mathrm{b}}$ & $77.2^{\prime}$ & $80.0^{\prime}$ \\
\hline $\mathrm{OM}^{2)}$ & $51.0 "$ & $50.1 "$ & $52.6 "$ & $81.4^{\prime}$ & $81.5^{\prime}$ & $53.1^{\mathrm{a}}$ & $57.5^{\mathrm{b}}$ & $80.5^{\prime}$ & $83.5^{\prime}$ \\
\hline $\mathrm{NDF}^{31}$ & $40.0 "$ & $40.2 ”$ & $40.3 "$ & 72.3" & $76.0^{\mathrm{f}}$ & $41.1^{\mathrm{b}}$ & $43.0^{\prime}$ & $71.1^{\mathrm{c}}$ & $72.6^{\mathrm{e}}$ \\
\hline $\mathrm{ADF}^{41}$ & $38.4 "$ & $39.6^{\mathrm{b}}$ & $41.0^{\mathrm{d}}$ & $69.5^{8}$ & $73.5^{\mathrm{h}}$ & $40.0^{\prime}$ & 41.4" & $68.3^{\mathrm{f}}$ & $68.1^{\prime}$ \\
\hline Hemicellulose & $42.1^{b}$ & $39.6 "$ & $39.4 "$ & $77.5^{\mathrm{d}}$ & $81.0 "$ & $42.4^{\prime}$ & $45.4 "$ & $76.6^{\mathrm{d}}$ & $81.0 "$ \\
\hline Cellulose & $41.0 ”$ & $42.8^{\mathrm{b}}$ & $41.7 "$ & 71.2” & $75.5^{\mathrm{d}}$ & $42.8^{\prime}$ & $43.0^{\mathrm{b}}$ & $70.8^{\prime}$ & $70.4^{\prime}$ \\
\hline $\mathrm{ABL}^{5)}$ & $31.2^{\mathrm{ab}}$ & $35.0^{\mathrm{bc}}$ & $40.6^{\prime}$ & $67.3 ”$ & $76.0^{\mathrm{f}}$ & $25.6 "$ & $32.4^{\mathrm{b}}$ & $58.8^{d}$ & $65.5 ”$ \\
\hline
\end{tabular}

1) Dry matter, 2) Organic matter, ${ }^{3)}$ Neutral detergent fibre, 4) Acid detergent fibre,

5) Acetyl bromide lignin,

6) Figures with different superscripts in the same row differ significantly $(\mathrm{P}<0.01)$. 
level and of hemicellulose and NDF with a $45 \%$ level. Digestibility of acetyl bromide lignin (ABL) was increased greatly by $\mathrm{NH}$, and $\mathrm{NH}_{3} \cdot \mathrm{SO}_{2}$ treatments, and the latter gave higher values than the former.

Ammonia may saponify ester bonds between lignin and hemicellulose (Chesson, 1988) and saturate $\mathbf{H}$ bonds linking the matrix polysaccharides (Dryden and Leng, 1988). Ammoniation increases the digestibility of the cell wall, perhaps partly by allowing intra-crystalline swelling of cellulose microfibrils (Millet et al., 1976).

The degree of improvement in straw digestibility tends to be higher with $\mathrm{NH}$, . SO, treatment compared to $\mathrm{NH}$, treatment. Dryden and Leng (1986) suggested that SO, injection after ammoniation increased treatment temperature to about $45^{\circ} \mathrm{C}$, causing an enhancement of the ammoniation process. Sulphuration alone had less effect on the digestibility of rice straw than that of $\mathrm{NH}$, or $\mathrm{NH}_{3} \cdot \mathrm{SO}_{2}$ treatment due to the mild condition $\left(40 \mathrm{~g} \mathrm{SO}_{2} / \mathrm{kg} \mathrm{DM}\right.$ straw for $24 \mathrm{hr}$ at $20^{\circ} \mathrm{C}$ ), as reported by Dryden and Leng (1986).

3. Relation between in sacco digestibility and lignin or silica of rice straw

Dry matter digestibility in sacco of rice straw was negatively correlated with lignin content (Fig. 1). Organic matter digestibility also had a inverse correlation with lignin content $(\mathrm{r}=-0.915, \mathrm{p}<0.01)$. Dry matter digestibility in sacco was positively correlated with lignin digestibility (Fig. 2). Lignin content is likely to be the major constraint on potential degradability (Smith et al., 1972). Chesson (1981) reported that when about $50 \%$ of the straw was degraded, further digestion of the cellulose and hemicellulose depended on the prior removal of lignin.

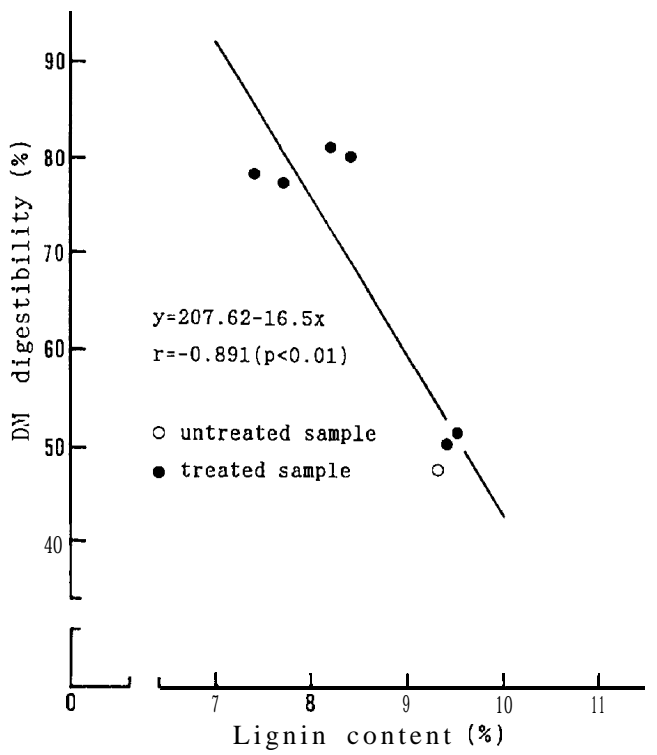

Fig. 1. Relation between in sacco dry matter (DM) digestibility and lignin content of rice straw. 


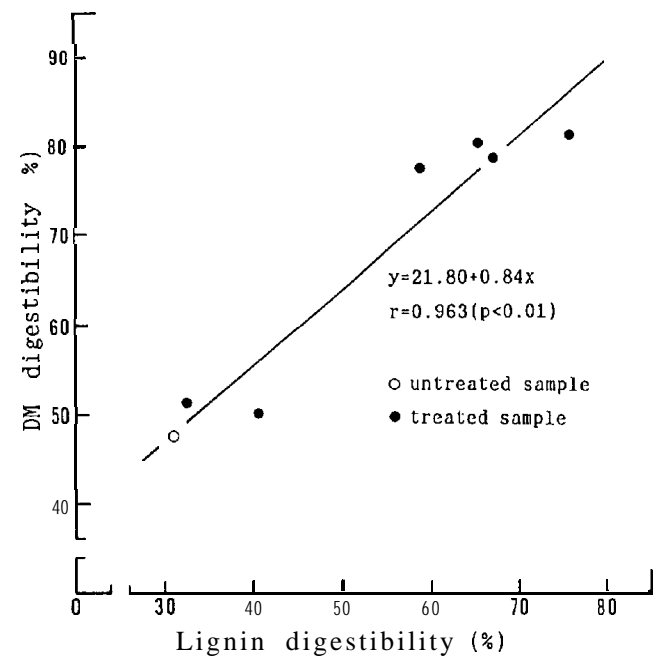

Fig. 2. Relation between in sacco dry matter (\%) digestibility and lignin digestibility of rice straw.

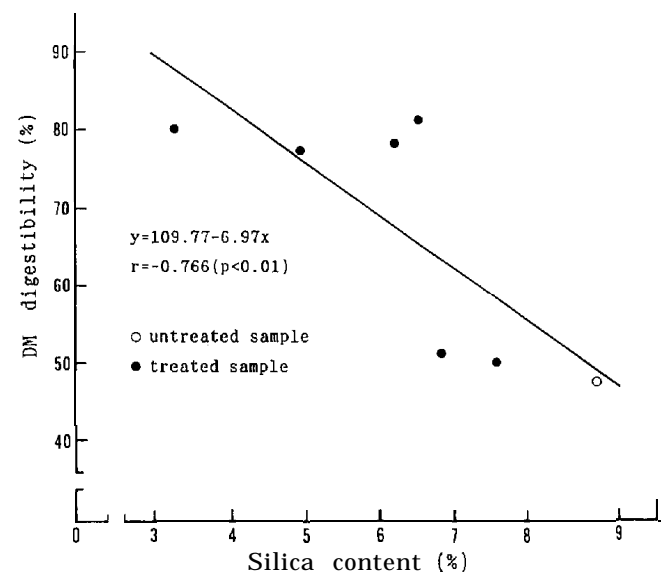

Fig. 3. Relation between in sacco dry matter (\%) digestibility and silica content of rice straw.

Digestibility in sacco of rice straw was negatively correlated with silica content (Fig. 3). Silica is a major factor limiting the digestibility of rice straw, which is relatively unlignified. The relationship of silica to digestibility is often affected by a compensatory association with lignin (Van Soest, 1982). Silica also complexes with essential mineral elements and influences their availability to rumen bacteria (Smith et al., 1975) and the activity of cellulolytic enzymes (Shimojo and Goto, 1989). Improvement in digestion of rice straw may be mainly caused by the decreases in content of lignin and silica and by the increased digestibility of lignin. 
From the results of this study, application of sulphur dioxide after ammonia treatment of rice straw was considered to be more effective than ammoniation alone for improving crude protein content and digestibility.

\section{REFERENCES}

AOAC. 1984. Official Methods of Analysis (14 th Ed). Association of Official Agricultural Chemists. Washington DC, pp. 16-19

Ben-Ghedalia, D. and J. Miron 1981 Effect of sodium hydroxide, ozone and sulphur dioxide on the composition and in vitro digestibility of wheat straw. J. Sci. Food Agric., 32 : 224-228

Ben-Ghedalia, D. and J. Miron 1984 The digestibility of wheat straw treated with sulphur dioxide. $J$. Agric. Sci., 102: 517-520

Borhami, B. E. A. and F. Sundst $\phi 11982$ Studies on ammonia-treated straw I. The effects of type and level of ammonia, moisture content and treatment time on the digestibility in vitro and enzyme soluble organic matter of oat straw. Anim. Feed Sci. Technol., 7: 45-51

Borhami, B. E. A., F. Sundst $\phi 1$ and T. H. Garmo 1982 Studies on ammonia treated straw. II. Fixation of ammonia in treated straw by spraying with acids. Anim. Feed sci. Technol., 7: 53-59

Chesson, A. 1981 Effect of sodium hydroxide on cereal straws in relation to the enhanced degradation of structural polysaccharides by rumen microorganisms. J. Sci. Food Agric., 32 :745-758

Chesson, A. 1988 Lignin-polysaccharide complexes of the plant cell wall and their effect on microbial degradation in the rumen. Anim. Feed Sci. Technol., 21: 219-228

Dryden, G. McL. and R. A. Leng 1986 Treatment of barley straw with ammonia and sulphur dioxide gases. Anim. Feed Sci. Technol., 14: 41-54

Dryden, G. McL. and R. A. Leng 1988 Effects of ammonia and sulphur dioxide gasses on the composition and digestion of barley straw. Anim. Feed Sci. Technol., 19: 121-133

Fahmy, S. T. M. and E. R. $\boldsymbol{\Phi}_{\text {rskov }} 1984$ Digestion and utilization of straw. 1. Effect of different chemical treatments on degradability and digestibility of barley straw by sheep. Anim. Prod., $38: 69-74$

Georing, H. K. and P. J. Van Soest 1970 Forage fiber analyses. USDA Agricultural Handbook, No. 379., Washington DC, pp. 1-12

Horton G. M. J., H. H. Nicholson and D. A. Christensen 1982 Ammonia and sodium hydroxide treatment of wheat straw in diets for fattening steers. Anim. Feed Sci. Technol., $7: 1-10$

Jackson, M. G. 1977 Review article : The alkali treated of straws. Anim. Feed Sci. Technol., 2 : 105130

Mehrez, A. Z. and E. R. $\boldsymbol{\Phi}$ rskov 1977 A study of the artificial fibre bag technique for determining the digestibility of feeds in the rumen.J.Agric. Sci., $88: 645-650$

Millet, M. A., A. J. Baker and L. D. Satter 1976 Physical and chemical pretreatments for enhancing cellulose saccharification. Biotechnol, Bioeng, Symp., No. 6, pp :125-153

Morrison, I. M. 1972 A semi-micro method for the determination of lignin and its use in predicting the digestibility of forage crops. J. Sci. Food Agric., $23: 455-463$

Shimojo, M. and I. Goto 1989 Effect of sodium silicate on forage digestion with rumen fluid of goats or cellulase using culture solutions adjusted for pH. Anim. Feed Sci. Technol., $24: 173-177$

Smith, G. S., H. K. Goering and C. H. Gordon 1972 Relationships of forage compositions with rates of cell wall digestion and indigestibility of cell walls. J. Dairy Sci., $55: 1140 \sim 1147$

Smith, G. S., R. T. Kelsey and A. B. Nelson 1975 Silica in range grass fibre digestibility. J. Anim. Sci., 41: 418 (abstract)

Streeter, C. L. and G. W. Horn 1982 Effect of treatment of wheat straw with ammonia and peracetic acid on digestibility in vitro and cell wall composition. Anim. Feed Sci, Technol., 7 : 325-329

Van Soest, P. J. 1982. Nutritional Ecology of the Ruminants. 0 \& B Books, Oregon 
Waagepetersen, J. and K. Vestergaard Thomsen 1977 Effect on digestibility and nitrogen content of barley straw of different ammonia treatments. Anim. Feed Sci. Technol., 2: 131-142

Waiss, A. C., J. Guggolz., G. 0. Kohler., H. G. Walker., Jr. and W. N. Garrett 1972 Improving the digestibility of straws for ruminant feed by a aqueous ammonia. J. Anim. Sci., $35: 109-112$ 